\title{
Inventarisasi Limbah Cair dan Padat Puskesmas di Surabaya Utara sebagai Upaya Pengelolaan Lingkungan
}

\author{
Menik Mustika, Atiek Moesriati dan Nieke Karnaningroem \\ Teknik Lingkungan, Fakultas Teknik Sipil dan Perencanaan, Institut Teknologi Sepuluh Nopember \\ (ITS) \\ Jl. Arief Rahman Hakim, Surabaya 60111 Indonesia \\ e-mail: moesriati@enviro.its.ac.id
}

\begin{abstract}
Abstrak- Puskesmas menghasilkan limbah pada setiap aktivitasnya. Limbah yang dihasilkan berbentuk cair dan padat. Limbah yang tidak tertangani dengan baik akan mencemari lingkungan disekitar Puskesmas. Maka, penelitian ini untuk mengetahui bagaimana proses penanganan pengelolaan limbah cair dan padat di Puskesmas Surabaya Utara apakah sesuai Peraturan Gubernur Jawa Timur No.72 Tahun 2013 tentang Baku Mutu Limbah Cair Untuk Kegiatan Rumah Sakit. Penelitian ini mengunakan pendekatan kualitatif dengan studi kasus deskriptif. Pengumpulan data dilakukan dengan wawancara, observasi, pendataan komposisi limbah cair, berat limbah padat,dan cara pengolahannya. Hal ini dilakukan dengan menggunakan kuesioner yang telah dibuat oleh peneliti dan dibacakan pertanyaan kepada pihak puskesmas. Pengelolaan limbah cair dan padat Pusat kesahatan masyarakat di Surabaya Utara tidak terlalu baik. Beberapa Puskesmas memiliki Instalasi Pengolahan Air Limbah (IPAL). Kuantitas limbah cair Puskesmas sebesar $1,47 \mathrm{~m}^{3} /$ hari - 2,57 $\mathrm{m}^{3} /$ hari , pada kualitas limbah cair beberapa parameter belum memenuhi baku mutu untuk TSS, $\mathrm{NH}_{3}-\mathrm{N}$ Bebas, $\mathrm{PO}_{4}$, dan Total Colifrom. Rekomendasi untuk Puskesmas yang telah memiliki IPAL adalah pengecekan proses aerasi, pembersihan media secara teratur dan penambahan dosis klor. Puskesmas yang tidak memiliki IPAL disarankan membangun IPAL jenis Biofilter dengan proses yang lebih baik dari sebelumnya. Limbah padat di golongkan menjadi 3 jenis yaitu limbah padat medis, basah dan kering. Berat rata - rata sampah basah mencapai 5625 gr, sampah kering 9439 gr, 2190 gr untuk sampah medis. Rekomendasi limbah padat adalah tempat sampah sesuai dengan jumlah volume sampah, dilengkapi dengan pelabelan, dan warna kantong plastik yang mengacu pada KepMenKes R.I. No.1428/MENKES/SK/XII/2006
\end{abstract}

Kata Kunci: Inventarisasi, Limbah cair, Limbah padat, Puskesmas

\section{PENDAHULUAN}

Jumlah limbah medis yang bersumber dari fasilitas kesehatan diperkirakan semakin lama semakin meningkat. Penyebabnya yaitu jumlah rumah sakit, puskesmas, balai pengobatan, maupun laboratorium medis yang terus bertambah. Pada Profil Kesehatan Indonesia tahun 2010 menyebutkan bahwa jumlah rumah sakit di Indonesia mencapai 1.632 unit. Sementara itu, jumlah puskesmas mencapai 9.005 unit. Fasilitas kesehatan yang lain diperkirakan jumlahnya akan terus meningkat dan tidak dijelaskan berapa jumlah yang tepat [1].
Limbah yang dihasilkan dari upaya medis puskesmas, poliklinik dan rumah sakit yaitu jenis limbah yang termasuk dalam kategori biohazard yaitu jenis limbah yang sangat membahayakan lingkungan, di mana banyak terdapat buangan virus, bakteri maupun zat-zat yang membahayakan lainnya sehingga harus dimusnahkan dengan cara dibakar dalam suhu di atas 800 derajat celcius. Kenyataanya, pengelolaan limbah medis yang berasal dari kegiatan medis di Indonesia masih dibawah standar profesional. Tidak sedikit rumah sakit yang membuang dan mengolah limbah medis tidak sesuai dengan peraturan yang berlaku. World Health Organization (WHO) pada tahun 2004 pernah melansir sekitar $0,14 \mathrm{~kg}$ timbunan limbah medis per hari di rumah sakit Indonesia atau sekitar 400 ton per tahun.

Limbah cair dan limbah padat yang berasal dan rumah sakit atau puskesmas dapat berfungsi sebagai media penyebaran penyakit bagi para petugas, penderita maupun masyarakat. Limbah alat suntik dan limbah lainnya dapat menjadi faktor risiko penularan berbagai penyakit seperti penyakit akibat infeksi nosokomial, penyakit HIV/AIDS, Hepatitis B dan C serta penyakit lain yang ditularkan melalui darah [2]. Suatu limbah medis jika tidak dikelola dengan baik akan berdampak buruk dan merugikan masyarakat yang berada di sekitar rumah sakit atau puskesmas maupun bagi rumah sakit atau puskesmas itu sendiri. Dampak negatif yang akan terjadi berupa gangguan pada kesehatan dan pencemaran lingkungan [3].

Pengelolaan limbah medis puskesmas memiliki permasalahan yang beraneka ragam. Limbah medis perlu dikelola sesuai dengan aturan yang ada sehingga pengelolaan harus dilakukan secara sistematis dan berkelanjutan. Selain itu, sumber daya manusia yang memahami permasalahan dan pengelolaan lingkungan menjadi sangat penting untuk mencapai kinerja lingkungan yang baik [4].

Luas wilayah Surabaya Utara kurang lebih 45,1 $\mathrm{km}^{2}$ terbagi menjadi 5 (lima) Kecamatan yaitu Kecamatan Bulak, Kecamatan Kenjeran, Kecamatan Semampir, Kecamatan Pabean Cantikan, Kecamatan Krembangan. Puskesmas penelitian ini berada di setiap kecamatan tersebut. Disetiap kecamatan terdapat satu atau lebih Puskesmas. Puskesmas yang dimaksud adalah Puskesmas Kenjeran, Puskesmas Tanah Kalikedinding, Puskesmas Bulak Banteng, Puskesmas Sidotopo Wetan, Puskesmas Wonokusumo, Puskesmas Pegirian, Puskesmas Perak Timur, Puskesmas Krembangan Selatan, Puskesmas Morokrembangan, Puskesmas Dupak.

Berdasarkan permasalahan yang ada, maka perlu dilakukan inventarisasi limbah cair dan padat di Puskesmas. Fasilitas kesehatan di wilayah Surabaya Utara semakin meningkat, Jumlah Puskesmas di Surabaya Utara adalah 10 puskesmas yang memiliki karakteristik berbeda-beda. Puskesmas di Surabaya Utara ada yang memiliki fasilitas rawat jalan dan ada juga yang menyediakan fasilitas rawat inap bagi masyarakat. Puskesmas yang menyediakan fasilitas rawat inap sangat bermasalah dengan limbah cair maupun padat. Oleh 
karena itu, perlu dilakukan inventarisasi limbah cair dan padat puskesmas di Surabaya Utara sebagai upaya pengelolaan lingkungan.

\section{METODE PENELITIAN}

\section{A. Umum}

Penelitian ini membahas tentang Inventarisasi limbah cair dan limbah padat yang terdapat pada Puskesmas wilayah Surabaya Utara. Analisis pada penelitian ini dilakukan dengan beberapa tahapan yaitu studi literature, pengumpulan data, dan analisis data. Jumlah puskesmas, jumlah pasien yang berada dipuskesmas, dan klasifikasi pengobatan semua termasuk dalam data sekunder. Data primer meliputi limbah cair dan limbah padat yang dihasilkan oleh masingmasing Puskmesmas serta penanganan yang dilakukan.

\section{B. Bagan Penelitian}

Bagan penelitian berdasarkan diagram alir yang telah dibuat dandijabarkan yaitu Ide penelitian, rumusan masalah, tujuan penelitian, studi literatur, pengambilan data, analisis pembahasan dan kesimpulan.

\section{Pengumpulan Data}

Data yang dikumpulkan berupa data primer dan data sekunder. Data primer adalah data yang diperoleh dengan adanya pengamatan langsung ke lapangan. Data primer dapat diperoleh melalui wawancara, kuisioner, observasi lapangan, atau sampling. Data sekunder dilakukan sebelum melakukan inventarisasi terhadap limbah cair dan limbah padat Puskesmas sebagai data penunjang penelitian.

Berikut ini adalah data-data primer yang akan diambil :

1) Wawancara dan kuisioner

Wawancara dan pembagian kuesioner pada 10 Puskesmas, dilakukan kepada petugas sanitasi setiap Puskesmas dengan sesi tanya jawab langsung mengenai pengolahan limbah.

Observasi

Observasi dilakukan untuk mengetahui jumlah maksimum pasien yang berbeda - beda tergantung jenis fasilitas, dan untuk mengetahui Pembakaran incinerator.

\section{2) Sampling}

Sampling dilakukan untuk mengukur influen dan efluen IPAL, efluen septik tank (black water), Air limbah laboratorium, berat limbah padat sesuai jenis dan sumbernya, dan insenerator. Pengukuran yang dilakukan untuk mengukur influen dan efluen IPAL, efluen septik tank, dan air limbah laboratorium adalah dengan mengukur volume, $\mathrm{pH}$, suhu, kadar konsentrasi BOD, COD, TSS, $\mathrm{NH}_{3}-\mathrm{N}$ bebas, $\mathrm{PO}_{4}$, dan total coliform. Analisis dilakukan dengan cara :

a. Volume

Perhitungan pada volume limbah cair maksimum dilakukan sesuai dengan yang tercantum pada Lampiran II Keputusan Gubernur Jawa Timur No. 45 Tahun 2012.

b. $\mathrm{pH}$

Metode untuk menganalisis ph adalah dengan menggunakan ph meter.

c. Suhu

Untuk mengukur suhu digunakan thermometer.

d. BOD

Uji pada BOD digunakan metode 5-day BOD test.

e. COD

Uji pada COD digunakan metode closed reflux, titimetric method.

\section{f. TSS}

Metode yang digunakan untuk mengukur Total Suspended Solid (TSS) adalah dengan menggunakan metode gravimetric.

\section{g. $\mathrm{NH}_{3}-\mathrm{N}$ bebas}

Analisis yang digunakan pada $\mathrm{NH}_{3}-\mathrm{N}$ bebas adalah dengan menggunakan Nesslerization Method yaitu dengan pembacaan nilai absorbansi menggunakan spektrofotometer visual. h. $\mathrm{PO}_{4}$

Kadar dari $\mathrm{PO}_{4}$ diidentrifikasi dengan menggunakan metode spektrofotometri.

i. Total Coliform

Total Coliform dianalisis dengan menggunakan metode Most Probable Number (MPN) dan menggunakan media Lactose Broth (LB) menggunakan tabung reaksi dengan tabung durham 3-3-3.

Data sekunder meliputi :

- Jumlah Puskesmas

- Jenis Puskesmas

- Jumlah pasien 2 tahun terakhir

- 10 penyakit terbanyak 2 tahun terakhir

- Jenis fasilitas yang ada di Puskesmas

- Gambar layout saluran air limbah Puskesmas

- Jenis IPAL dan insinerator yang digunakan

\section{HASIL DAN PEMBAHASAN}

\section{A. Hasil Survey dan Kondisi Umum Puskesmas}

Jumlah Puskesmas di Surabaya Utara menurut Dinas Kesehatan Kota Surabaya pada tahun 2015 mencapai 10 Puskesmas. Puskesmas di Surabaya Utara memiliki 2 waktu pelayanan yaitu pada jam 07.30 - 14.30 WIB dan 14.30 - 17.30 WIB. Puskesmas memiliki hari operasional 6 hari dalam satu minggu, yaitu dari hari Senin - Sabtu. Jumlah pasien dan tipe Puskesmas berbeda - beda. Jumlah pasien terbanyak terdapat di Puskesmas Dupak dengan jenis Puskesmas rawat inap. Menurut hasil observasi, setiap puskesmas memiliki pelayanan yang berbeda - beda tergantung tenaga kesehatan yang ada di Puskesmas tersebut dan wilayah di sekitar Puskesmas. Pada Tabel 4.1 adalah salah satu contoh 10 penyakit terbanyak di Puskesmas Krembangan Selatan selama 2 tahun terakhir.

Tabel 4.1

Penyakit Terbanyak pada Puskesmas Krembangan Selatan

\begin{tabular}{llll}
\hline \hline No & Jenis Penyakit & Tahun & \\
& & 2014 & 2015 \\
\hline 1 & $\begin{array}{l}\text { Influenza with other respiratory } \\
\text { manifestations, virus not identified }\end{array}$ & & $\sqrt{ }$ \\
2 & $\begin{array}{l}\text { Influenza with other manifestations, virus } \\
\text { not identified }\end{array}$ & $\sqrt{ }$ & $\sqrt{ }$ \\
3 & Acute laryngopharyngitis & $\sqrt{ }$ & $\sqrt{ }$ \\
4 & Diarrhoea and gastroenteritis of & $\sqrt{ }$ & $\sqrt{ }$ \\
& presumed infection origin & \\
5 & Allergic contact dermatitis due to metals & $\sqrt{ }$ & $\sqrt{ }$ \\
6 & Essential (primary) hypertansion & & $\sqrt{ }$ \\
7 & Besnier's prurigo & & $\sqrt{ }$ \\
8 & Seronegative rheunatoid arthritis & & $\sqrt{ }$ \\
9 & Super vision of other normal pregnancy & $\sqrt{ }$ & $\sqrt{ }$ \\
10 & Fever, unspecified & $\sqrt{ }$ & \\
11 & Headache & $\sqrt{ }$ & \\
12 & Myalgia & $\sqrt{ }$ \\
13 & Dyspepsia & $\sqrt{ }$ \\
14 & Acute haemorrhagic gastritis & $\sqrt{ }$ & \\
\hline \hline
\end{tabular}

\section{B. Identifikasi Kualitas dan Kuantitas Limbah Puskesmas}

Limbah cair yang dihasilkan bersifat toksik dan non toksik tergantung dari kegiatannya. Kualitas limbah cair dari pengelolaan air limbah yang telah dilakukan oleh setiap Puskesmas di Surabaya Utara berbeda - beda. Beberapa Puskemas di Surabaya Utara tidak memiliki IPAL jenis Biofilter (Puskesmas Kenjeran, Tanah Kalikedinding, Pegirian, Perak Timur, Morokrembangan) dan yang telah memiliki IPAL adalah Puskesmas Krembangan Selatan, Dupak, Wonokusumo, Bulak Banteng, dan Sidotopo Wetan.

Sampling air limbah akan di lakukan pada Puskesmas yang memiliki IPAL dan septik tank. Kemudian, air limbah IPAL dan 
septik tank dapat dianalisis di laboratorium. Analisis ini bertujuan untuk mengetahui karakteristik limbah cair Puskesmas di Surabaya Utara sudah memenuhi baku mutu yang sesuai dengan SK Gubernur Jawa Timur no 72 tahun 2013 yang memiliki 8 parameter. Parameter yang akan diuji yaitu suhu, $\mathrm{pH}, \mathrm{BOD}_{5}, \mathrm{COD}, \mathrm{TSS}, \mathrm{NH}_{3}-\mathrm{N}$ Bebas, dan Total Coliform kemudian dibandingkan dengan baku mutu. Pada influen Puskesmas Sidotopo Wetan tidak dilakukan penyemplingan karena keterbatasan ijin. Sedangkan IPAL Puskesmas Dupak mengalami kerusakan.

1) Analisis Suhu

Suhu limbah cair yang dihasilkan setiap Puskesmas bervariasi. Menurut baku mutu untuk parameter suhu adalah $30^{\circ} \mathrm{C}$. Tabel 4.2 merupakan hasil parameter suhu pada IPAL dan Tabel 4.3 merupakan hasil parameter suhu pada septik tank.

Tabel 4.2

Karakteristik Limbah Cair IPAL Berdasarkan Parameter Suhu

\begin{tabular}{llll}
\hline \hline No & Daftar Puskesmas & $\begin{array}{l}\left({ }^{\circ} \mathrm{C}\right) \\
\text { Inlet }\end{array}$ & Outlet \\
\hline 1 & Bulak Banteng & 28 & 29 \\
2 & Sidotopo Wetan & - & 29 \\
3 & Wonokusumo & 30 & 30 \\
4 & Krembangan Selatan & 32 & 30 \\
\hline \hline Sumber: Hasil survey
\end{tabular}

Tabel 4.3

Karakteristik Limbah Cair Septik tank Berdasarkan Parameter Suhu

\begin{tabular}{ccc}
\hline \hline No & Daftar Puskesmas & Pengambilan \\
\hline 1 & Tanah Kalikedinding & 29 \\
\hline \hline Sumber: Hasil survey
\end{tabular}

Berdasarkan Tabel 4.2 dan Tabel 4.3 menunjukkan bahwa parameter suhu pada air limbah yang dihasilkan oleh IPAL dan septik tank pada Puskesmas di Surabaya Utara sesuai dengan Peraturan Gubernur Jawa Timur No. 72 Tahun 2013.

2) Analisis $p H$

Menurut SK Gubernur Jawa Timur No. 72 Tahun 2013 baku mutu untuk parameter $\mathrm{pH}$ adalah $6-9$. Dibawah ini adalah tabel yang menyatakan karakteristik limbah cair IPAL berdasarkan parameter pH (Tabel 4.4) dan karakteristik limbah cair septik tank berdasarkan parameter $\mathrm{pH}$ (Tabel 4.5)

Tabel 4.4

Karakteristik Limbah Cair IPAL Berdasarkan Parameter $\mathrm{pH}$

\begin{tabular}{llll}
\hline \hline No & Daftar Puskesmas & $\begin{array}{l}\text { Pengambilan } \\
\text { Inlet }\end{array}$ & Outlet \\
\hline 1 & Bulak Banteng & 7,25 & 8,05 \\
2 & Sidotopo Wetan & - & 7,00 \\
3 & Wonokusumo & 7,15 & 7,30 \\
4 & Krembangan Selatan & 6,30 & 6,10 \\
\hline \hline \multicolumn{2}{l}{ Sumber: Hasil analisis laboratorium manajemen lingkungan, 2016 }
\end{tabular}

Tabel 4.5

Karakteristik Limbah Cair Septik tank Berdasarkan Parameter pH

\begin{tabular}{ccc}
\hline \hline No & Daftar Puskesmas & Pengambilan \\
1 & Tanah Kalikedinding & 7,30 \\
\hline \hline & Sumber: Hasil analisis laboratorium manajemen lingkungan, 2016
\end{tabular}

Berdasarkan Tabel 4.4 dan Tabel 4.5 pada uji parameter $\mathrm{pH}$ di Puskesmas Surabaya Utara tidak ada yang melebihi baku mutu, sehingga masih aman jika dibuang ke lingkungan sekitar.

3) Analisi COD

Karakteristik limbah cair yang dihasilkan oleh Puskesmas ditentukan melalui analisis COD. Angka COD adalah ukuran bagi pencemaran air oleh zat - zat, angka COD yang didapat akan dibandingkan dengan baku mutu yaitu $80 \mathrm{mg} / \mathrm{L}$. Hasil analisis COD dapat dilihat pada tabel 4.6 dan 4.7

Tabel 4.6

Karakteristik Limbah Cair Septik tank Berdasarkan Parameter COD

\begin{tabular}{ccc}
\hline \hline No & Daftar Puskesmas & $\begin{array}{c}\text { Pengambilan } \\
(\mathrm{mg} / \mathrm{L})\end{array}$ \\
\hline 1 & Tanah Kalikedinding & 60 \\
\hline \hline \multicolumn{2}{c}{ Sumber: Hasil analisis laboratorium manajemen lingkungan, 2016}
\end{tabular}

Tabel 4.7

Karakteristik Limbah Cair IPAL Berdasarkan Parameter COD

\begin{tabular}{llll}
\hline \hline \multirow{2}{*}{ No } & \multirow{2}{*}{ Daftar Puskesmas } & $(\mathrm{mg} / \mathrm{L})$ & \\
& Inlet & Outlet \\
\hline 1 & Bulak Banteng & 10 & 7 \\
2 & Sidotopo Wetan & - & 31 \\
3 & Wonokusumo & 13 & 4 \\
4 & Krembangan Selatan & 4 & 10 \\
\hline \hline \multicolumn{2}{l}{ Sumber: Hasil analisis laboratorium manajemen lingkungan, 2016 }
\end{tabular}

Berdasarkan dari Tabel 4.6 dan Tabel 4.7 dapat diketahui bahwa limbah cair yang dihasilkan dari IPAL Puskesmas maupun septik tank Puskesmas memenuhi baku mutu. Sehingga untuk parameter COD masih aman jika dibuang ke lingkungan.

4) Analisis TSS

Pada analisis penentuan zat padat tersuspensi (TSS) bertujuan untuk mengetahui kekuatan pencemaran air limbah, dan juga untuk efisiesi pengolahan air. Konsentrasi padatan tersuspensi limbah cair pada Puskesmas Surabaya Utara dapat dilihat pada Tabel 4.8 dan 4.9 Tabel 4.8 Karakteristik Limbah Cair IPAL Berdasarkan Parameter TSS

\begin{tabular}{cccc}
\hline \hline \multirow{2}{*}{ No } & Daftar Puskesmas & Inlet & Outlet \\
\hline 1 & Bulak Banteng & 14 & 13 \\
2 & Sidotopo Wetan & - & 16 \\
3 & Wonokusumo & 110 & 12 \\
4 & Krembangan Selatan & 18 & 14 \\
\hline \hline
\end{tabular}

Sumber: Hasil analisis laboratorium manajemen lingkungan, 2016

Tabel 4.9

Karakteristik Limbah Cair Septik tank Berdasarkan Parameter TSS

\begin{tabular}{ccc}
\hline \hline No & Daftar Puskesmas & $\begin{array}{c}\text { Pengambilan } \\
(\mathrm{mg} / \mathrm{L})\end{array}$ \\
\hline 1 & Tanah Kalikedinding & 20 \\
\hline \hline
\end{tabular}

Sumber: Hasil analisis laboratorium manajemen lingkungan, 2016

Berdasarkan Tabel 4.8 dan 4.9 konsentrasi limbah hasil pengolahan IPAL maupun septik tank tidak ada yang melebihi baku mutu sebesar $30 \mathrm{mg} / \mathrm{L}$.

5) Analisis $\mathrm{BOD}_{5}$

BOD5 adalah parameter umum yang digunakan dalam menyatakan kekuatan air limbah dimana dapat dilihat dari konsentrasi air limbah. Dapat dilihat konsentrasi BOD 5 pada Table 4.10 dan Tabel 4.11

Tabel 4.10

Karakteristik Limbah Cair IPAL Berdasarkan Parameter BOD 5

\begin{tabular}{llll}
\hline \hline \multirow{2}{*}{ No } & Daftar Puskesmas & $\begin{array}{l}(\mathrm{mg} / \mathrm{L}) \\
\text { Inlet }\end{array}$ & Outlet \\
\hline 1 & Bulak Banteng & 6 & 4 \\
2 & Sidotopo Wetan & - & 19 \\
3 & Wonokusumo & 8 & 2 \\
4 & Krembangan Selatan & 6 & 2 \\
\hline \hline \multicolumn{2}{l}{ Sumber: Hasil analisis laboratorium manajemen lingkungan, 2016 }
\end{tabular}

Tabel 4.11

Karakteristik Limbah Cair Septik tank Berdasarkan Parameter BOD 5

\begin{tabular}{lll}
\hline \hline No & Daftar Puskesmas & $\begin{array}{l}\text { Pengambilan } \\
(\mathrm{mg} / \mathrm{L})\end{array}$ \\
\hline 1 & Tanah Kalikedinding & 38 \\
\hline \hline
\end{tabular}


Sumber: Hasil analisis laboratorium manajemen lingkungan, 2016

Berdasarkan Tabel 4.10 dan Tabel 4.11, bahwa nilai BOD 5 tidak ada yang melebihi baku mutu. Besar nilai $\mathrm{BOD}_{5}$ menunjukkan konsentrasi bahan organik yang terdapat pada limbah cair Puskesmas. 6) Analisis $\mathrm{PO}_{4}$

Salah satu parameter uji kualitas air limbah adalah kadar phospat ( $\left.\mathrm{PO}_{4}\right)$. Konsentrasi kadar phospat dapat dilihat pada Tabel 4.12 dan Tabel 4.13. Baku mutu menurut SK Gubernur Jawa Timur No.72 Tahun 2013 adalah $2 \mathrm{mg} / \mathrm{L}$.

Tabel 4.12

Karakteristik Limbah Cair IPAL Berdasarkan Parameter $\mathrm{PO}_{4}$

\begin{tabular}{llll}
\hline \hline No & Daftar Puskesmas & $(\mathrm{mg} / \mathrm{L})$ & Outlet \\
\hline 1 & Bulak Banteng & Inlet & 0,27 \\
2 & Sidotopo Wetan & 0,42 & 4,10 \\
3 & Wonokusumo & - & 2,40 \\
4 & Krembangan Selatan & 2,87 & 0,48 \\
\hline \hline \multicolumn{2}{l}{ Sumber: Hasil analisis laboratorium manajemen lingkungan, 2016 }
\end{tabular}

Tabel 4.13

Karakteristik Limbah Cair Septik tank Berdasarkan Parameter $\mathrm{PO}_{4}$

\begin{tabular}{lcc}
\hline \hline No & Daftar Puskesmas & $\begin{array}{c}\text { Pengambilan } \\
(\mathrm{mg} / \mathrm{L})\end{array}$ \\
\hline 1 & Tanah Kalikedinding & 2,53 \\
\hline \hline
\end{tabular}

Berdasarkan hasil Tabel 4.12 dan Tabel 4.13 bahwah hasil analisis tertinggi adalah outlet Puskesmas Sidotopo Wetan dengan nilai 4,10 $\mathrm{mg} / \mathrm{L}$. Kandungan phospat yang tinggi dapat menyebabkan eutrofikasi, yaitu tumbuhnya lumut atau microalgae pada badan air yang menerima limbah cair tersebut.

7) Analisis $\mathrm{NH}_{3}-\mathrm{N}$ Bebas

$\mathrm{NH}_{3}-\mathrm{N}$ Bebas atau biasa disebut nitrogen ammonia. Konsentrasi nitrogen ammonia dapat dilihat pada Tabel 4.14 dan Tabel 4.15 Tabel 4.14

Karakteristik Limbah Cair IPAL Berdasarkan Parameter $\mathrm{NH}_{3}-\mathrm{N}$ Bebas

\begin{tabular}{llll}
\hline \hline No & Daftar Puskesmas & $(\mathrm{mg} / \mathrm{L})$ & \\
& & Inlet & Outlet \\
\hline 1 & Bulak Banteng & 14 & 13 \\
2 & Sidotopo Wetan & - & 44,40 \\
3 & Wonokusumo & 30,7 & 0,35 \\
4 & Krembangan Selatan & 10,41 & 0,01 \\
\hline \hline
\end{tabular}

Sumber: Hasil analisis laboratorium manajemen lingkungan, 2016

Tabel 4.15

Karakteristik Limbah Cair Septik tank Berdasarkan Parameter $\mathrm{NH}_{3}-\mathrm{N}$ Bebas

\begin{tabular}{lll}
\hline \hline No & Daftar Puskesmas & $\begin{array}{l}\text { Pengambilan } \\
(\mathrm{mg} / \mathrm{L})\end{array}$ \\
\hline 1 & Tanah Kalikedinding & 44,99 \\
\hline
\end{tabular}

Sumber: Hasil analisis laboratorium manajemen lingkungan, 2016

Berdasarkan hasil Tabel 4.14 dan Tabel 4.15 ada beberapa

Puskesmas di Surabaya Utara yang melebihi baku mutu, yaitu

Puskesmas Bulak Banteng, Puskesmas Sidotopo Wetan, dan

Puskesmas Tanah Kalikedinding. Baku mutu untuk parameter nitrogen ammonia sesuai dengan SK Gubernur Jawa Timur No.72

Tahun 2013 adalah 0,1 mg/L.

8) Analisis Total Coliform

Analisis Total Coliform bertujuan melihat adanya kemungkinan pencemaran oleh tinja. Nilai Total Coliform dapat dilihat pada Tabel 4.16 dan Tabel 4.17

Tabel 4.16

Karakteristik Limbah Cair IPAL Berdasarkan Parameter Total Coliform

\begin{tabular}{llll}
\hline \hline No & Daftar Puskesmas & (MPN/100 mL) & \\
& & Inlet & Outlet \\
\hline 1 & Bulak Banteng & $80 \times 10^{8}$ & 20.000 \\
2 & Sidotopo Wetan & - & 33.000 \\
3 & Wonokusumo & $40 \times 10^{8}$ & 20.000 \\
4 & Krembangan Selatan & $170 \times 10^{8}$ & 70.000 \\
\hline \hline
\end{tabular}

Sumber: Hasil analisis laboratorium manajemen lingkungan, 2016

Tabel 4.17

Karakteristik Limbah Cair Septik tank Berdasarkan Parameter Total Coliform

\begin{tabular}{ccc}
\hline \hline No & Daftar Puskesmas & $\begin{array}{c}\text { Pengambilan } \\
(\mathrm{MPN} / 100 \mathrm{~mL})\end{array}$ \\
\hline 1 & Tanah Kalikedinding & 17.000 \\
\hline \hline
\end{tabular}

Sumber: Hasil analisis laboratorium manajemen lingkungan, 2016

Berdasarkan Tabel 4.16 dan Tabel 4.17 bahwa Puskesmas masih belum memenuhi baku mutu untuk parameter Total Coliform. Kadar coliform yang tinggi disebabkan pada bak klorinasitidak berfungsi, sehingga perlu diberi penambahan dosis klor pada unit IPAL.

Kuantitas limbah cair dapat diketahui dari presentase jumlah air bersih yang digunakan Pengamatan meteran air hanya di lakukan pada Puskesmas yang memiliki jumlah pasien paling banyak dan paling sedikit. Hal ini bertujuan agar mendapatkan rentan pemakaian air pada Puskesmas. Puskesmas yang akan dilakukan pengamatan adalah Puskesmas Dupak dan Puskesmas Bulak Banteng. Dari hasil pengamatan didapatkan hasil pemakaian air bersih dalam satu hari sebesar $3276,54 \mathrm{~m}^{3} /$ hari $-3272,87 \mathrm{~m}^{3} / \mathrm{hari}=3,67 \mathrm{~m}^{3} / \mathrm{hari}$. Puskesmas Bulak Banteng dalam satu hari 1129,27 $\mathrm{m}^{3} / \mathrm{hari}-1127,16 \mathrm{~m}^{3} / \mathrm{hari}=$ $2,11 \mathrm{~m}^{3} /$ hari. Asumsi untuk untuk air limbah adalah $70 \%$ dari pemakaian air bersih, karena $30 \%$ dari pemakaian air. Kuantitas air limbah yang dihasilkan pada Puskesmas yaitu:

- Dupak $=70 \%$ x 3,67 m²/hari $=2,57 \mathrm{~m}^{3} /$ hari

- Bulak Banteng $=70 \% \times 2,11 \mathrm{~m}^{3} /$ hari $=1,47 \mathrm{~m}^{3} /$ hari

Perhitungan tersebut menunjukkan bahwa debit air limbah yang dihasilkan Puskesmas per harinya berkisar 2,57 $\mathrm{m}^{3} /$ hari $-1,47$ $\mathrm{m}^{3} /$ hari.

\section{Limbah Cair Medis}

Limbah medis berbentuk cair berasal dari kegiatan di Puskesmas. Kegiatan berasal dari masing - masing poli, Laboratorium dan Unit Gawat Darurat(UGD). Kuantitas pada limbah cair medis di dapatkan dari perhitungan rata - rata limbah Laboratorium pada satu wadah penampung. Wadah yang digunakan pada setiap Puskesmas bervolume 10L, setiap 1 minggu limbah akan dibuang langsung ke wastafle dan mengalir ke septik tank. Volume limbah cair didapatkan dengan cara:

Volume limbah laboratorium $=10 \mathrm{~L} / 6$ hari $=1,67 \mathrm{~L} / \mathrm{hari}$

Analisis untuk parameter limbah cair dilakukan pada sampel limbah cair. Parameter yang digunakan sesuai dengan peraturan Gubernur Jawa Timur No. 72 Tahun 2013. Puskesmas melakukan pengelolaan limbah cair medis dengan cara yang berbeda - beda. Pada puskesmas yang telah memiiki IPAL, limbah akan dialirkan menuju IPAL. Sedangkan, Puskesmas yang tidak memiliki IPAL langsung dibuang ke septik tank adapun yang menggunakan sumur resapan. Hasil analisis dapat dilihat pada Tabel 4.18

4.18 Hasil Analisi Limbah Laboratorium

\begin{tabular}{|c|c|c|c|c|c|c|c|c|c|}
\hline \multirow[b]{2}{*}{ No } & \multicolumn{7}{|c|}{ Hasil Analisis Parameter Air Limbah Laboratorium } & \multirow[b]{2}{*}{$\begin{array}{l}\text { Analisi } \\
\text { s P } \\
(\mathrm{mg} / \mathrm{L})\end{array}$} & \multirow[b]{2}{*}{$\begin{array}{l}\text { Total } \\
\text { Colifor } \\
\mathrm{m}\end{array}$} \\
\hline & $\begin{array}{l}\text { Daftar } \\
\text { Puskesmas }\end{array}$ & $\mathrm{pH}$ & Suhu & BOD & $\begin{array}{l}\mathrm{COD} \\
(\mathrm{mg} / \mathrm{L})\end{array}$ & $\begin{array}{l}\text { TSS } \\
(\mathrm{mg} / \mathrm{L})\end{array}$ & $\begin{array}{l}\text { Analisis } \\
\mathrm{N}(\mathrm{mg} / \mathrm{L})\end{array}$ & & \\
\hline 1 & Kenjeran & $\begin{array}{l}10,0 \\
5\end{array}$ & 25 & 19 & 32 & 540 & 17,56 & 0,11 & 12000 \\
\hline 2 & $\begin{array}{l}\text { Tanah } \\
\text { Kalikedinding }\end{array}$ & 7,20 & 28 & 4 & 7 & 18 & 6,80 & 1,28 & 20000 \\
\hline 3 & Pegirian & 7,70 & 26 & 680 & 1392 & 20 & 62,35 & 0 & 17000 \\
\hline 4 & $\begin{array}{l}\text { Morokrembanga } \\
\mathrm{n}\end{array}$ & 9 & 26 & 12 & 21 & 34 & 25,49 & 2,70 & $<3$ \\
\hline 5 & Dupak & 7,60 & 27 & 620 & 1080 & 16 & 24,98 & 0,24 & 70000 \\
\hline 6 & Perak Timur & 7,40 & 26 & 6460 & 11136 & 18 & 52,60 & 88,77 & 70000 \\
\hline
\end{tabular}

Sumber: Hasil analisis laboratorium manajemen lingkungan , 2016

Dapat dilihat pada Tabel 4.18 menyatakan bahwa kandungan total coliform pada Puskesmas Morokrembangan sangat kecil. Hal ini disebabkan karena limbah laboratorium tidak mengandung total coliform. Sifat toksik ini menyebabkan air limbah tidak mengandung total coliform. Pada Puskesmas Pegirian nilai phospat yang 
dihasilkan adalah nol. Hal ini disebabkan karena limbah laboratorium puskesmas pegirian tidak mengandung deterjen.

\section{Limbah Padat Domestik}

Setiap Puskesmas akan menghasilkan limbah padat domestik yang berasal dari kegiatan yang terjadi di Puskesmas. Perhitungan jumlah limbah padat domestik berdasarkan sumbernya dibedakan menjadi 2 jenis yaitu limbah padat domestik basah dan kering. Sampah kering terdiri terdiri dari plastik, kerdus, kaca, botol minum, styrofoam, kaleng, dan kertas. Sampah basah terdiri dari sisa makanan, kulit/biji buah, daun, kayu, tulang hewan. Penimbangan dilakukan di 10 Puskesmas di Surabaya Utara. Jumlah sampah padat non medis terbanyak terdapat pada Puskesmas Dupak. Berikut adalah hasil penimbangan di Puskesmas dapat dilihat pada Gambar 4.1. Pada Puskesmas Dupak dapat dilihat pada penimbangan hari ke 2 merupakan jumlah tertinggi itu dikarenakan kegiatan meningkat. Perbedaan berat sampah perhari pada masing - masing Puskesmas dapat dilihat pada Gambar 4.1 dan 4.2

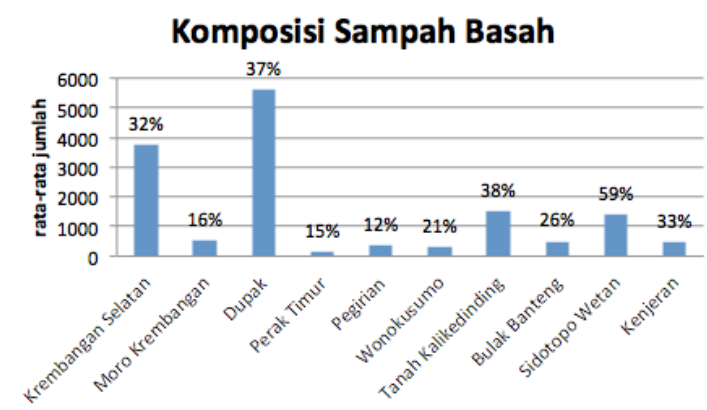

Gambar 4.1 Komposisi Sampah Basah di Puskesmas Surabaya Utara

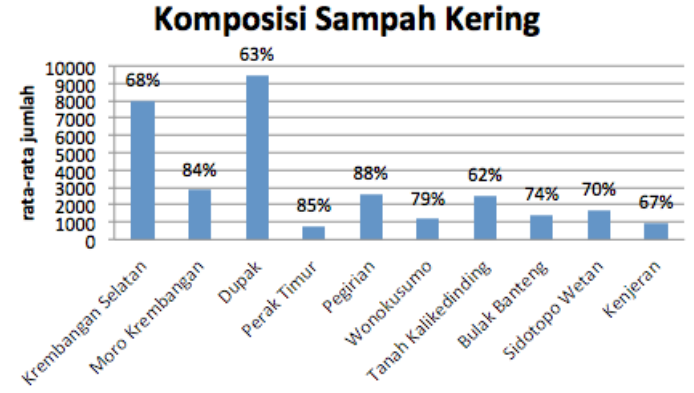

Gambar 4.2 Komposisi Sampah Kering di Puskesmas Surabaya Utara

Pada grafik diatas merupakan jumlah rata - rata dan komposisi selama lima hari disetiap Puskesmas di Surabaya Utara.

Limbah Padat Medis

Limbah padat medis fasilitas kesehatan menurut DepKes RI di kelompokan menjadi 9 kelompok. Akan tetapi, berdasarkan hasil survey penimbangan limbah padat medis di Puskesmas hanya dapat mengklasifikasikan menjadi 3 jenis yaitu infeksius, infeksius benda tajam, dan farmasi di karenakan fasilitas kesehatan pada Puskesmas berbeda dengan Rumah Sakit. Penimbangan dilakukan di 10 Puskesmas. Perbedaan antara berat komposisi per Puskesmas dapat dilihat pada Gambar 4.3, Gambar 4.4, dan Gambar 4.5

\section{Komposisi Sampah Infeksius Benda} Tajam

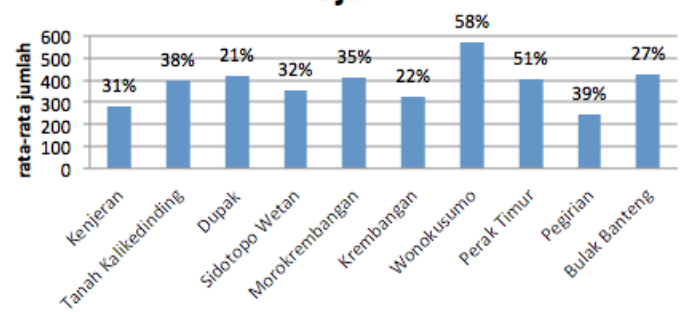

Gambar 4.3 Perbandingan Komposisi Sampah Infeksius Benda Tajam per Puskesmas

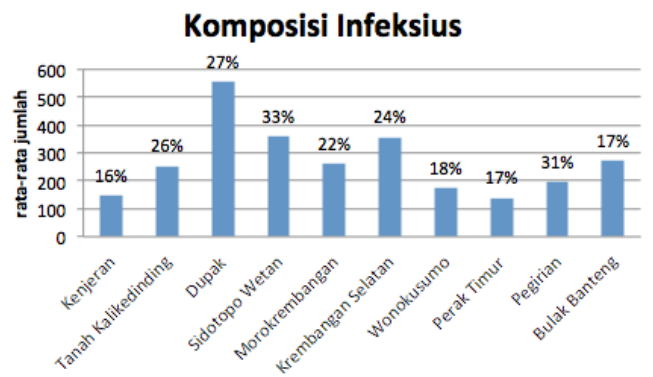

Gambar 4.4 Perbandingan Komposisi Sampah Infeksius per Puskesmas

\section{Komposisi Sampah Farmasi}

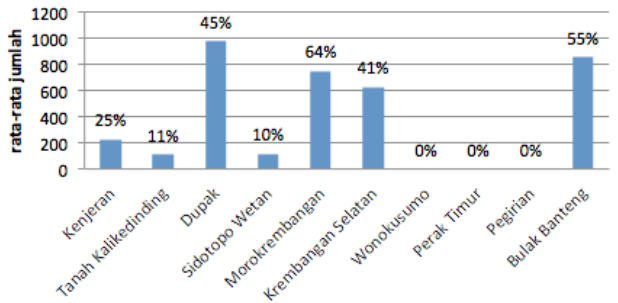

Gambar 4.5 Perbandingan Komposisi Sampah Farmasi per Puskesmas

Menurut gambar diatas pada Puskesmas wonokusumo mendapat 58\% komposisi infeksius benda tajam sedangkan pada sampah farmasi mendapat $0 \%$ itu di karenakan, hasil dari beberapa Puskesmas menunjukkan bahwa tidak adanya ke seimbangan. Hal itu di sebabkan fasilitas kesehatan yang di miliki oleh masing - masing Puskesmas, jumlah pasien, luas Puskesmas, jumlah karyawan yang ada, dan jumlah penyakit yang dilayani oleh Puskesmas. Pewadahan limbah padat seharusnya diawali dengan pemilahan. Menurut peraturan Kepmenkes No.1204 tahun 2004 limbah infeksius benda tajam harus ditampung menggunakan safety box Berdasarkan PP no. 101 tahun 2014, wadah sampah medis harus anti karat, anti bocor. Limbah medis disimpan dan dikumpulkan di tempat tertutup dan terkunci. Pengangkutan limbah padat medis dilakukan oleh pihak ke tiga yaitu PT. Putra Restu Ibu Abadi (PRIA) yang berlokasi di Mojokerto. Limbah medis harus diolah dengan pembakaran menggunakan insenerator, sesuai dengan keputusan Kepmenkes No. 1204 tahun 2004.

\section{Rekomendasi Pengolahan Limbah Cair Dan Padat Puskesmas}

IPAL pada Puskesmas di Surabaya Utara ada beberapa kesalahan didalam pengelolaannya, hal tersebut dapat dilihat pada hasil uji laboratorium. Nilai tinggi terdapat pada parameter $\mathrm{PO}_{4}$ dan total Coliform hal ini dapat dikatakan bahwa pengolahan biofilter tidak berjalan sempurna.

Rekomendasi bagi Puskesmas yang memiliki IPAL yaitu:

1) Menurunkan kadar $\mathrm{PO}_{4}$ yang tinggi dapat dilakukan pengecekan ulang pada waktu aerasi

2) Menurunkan kadar Total Coliform dapat dilakukan penambahan dosis klor

3) Rekomendasi bagi Puskesmas Surabaya Utara yang belum memiliki IPAL adalah dengan membangun IPAL jenis biofilter dengan proses yang lebih baik dari sebelumnya.

Rekomendasi untuk limbah padat non medis dengan memisahkan sampah basah dan sampah kering. Pelabelan menggunakan gambar dan tulisan agar pembuang dapat membedakan sampah basah dan sampah kering. Direncanakan tempat sampah sesuai dengan volume timbulan sampah, sehingga didapat volume sampah seperti dibawah ini. 
Volume sampah kering

Volume sampah=10.370grx $1 / 1000 \mathrm{~kg}=10,37 \mathrm{~kg} / 100 \mathrm{~kg} / \mathrm{m}^{3}=10,37 \mathrm{~L}$ Volume sampah basah

Volume sampah $=6.000 \mathrm{gr} \times 1 / 1000 \mathrm{~kg}=6 \mathrm{~kg} / 100 \mathrm{~kg} / \mathrm{m}^{3}=6 \mathrm{~L}$

Volume sampah medis

Volume sampah=3820 gr x $1 / 1000 \mathrm{~kg}=3,82 \mathrm{~kg} / 100 \mathrm{~kg} / \mathrm{m}^{3}=38,2 \mathrm{~L}$

\section{KESIMPULAN}

A. Kuantitas dan Kualitas limbah cair

- Pada kinerja IPAL kurang maksimal, sehingga masih ada parameter yang belum memenuhi baku mutu SK Gubernur Jawa Timur No.72 tahun $2013 \mathrm{PO}_{4}, \mathrm{NH}_{3}-\mathrm{N}$ bebas dan Total Coliform

- Secara kuantitas limbah cair yang dihasilkan oleh masing masing Puskesmas diwilayah Surabaya Utara mencapai 2,57 $\mathrm{m}^{3} /$ hari $-1,47 \mathrm{~m}^{3} /$ hari.

B. Kuantitas dan Komposisi limbah padat

- Limbah Padat domestik dibedakan menjadi 2 jenis yaitu sampah basah dan sampah kering
Kesehatan Kota Surabaya, dan Badan Lingkungan Hidup Kota Surabaya atas bantuan dan dukungan dalam penyelesaian penelitian ini.

\section{DAFTAR PUSTAKA}

[1] Kemenkes. 2011. Profil Kesehatan Indonesia tahun 2010. Kementerian Kesehatan Republik Indonesia, Jakarta

[2] Departemen Kesehatan Republik Indonesia. 2004, Kepmenkes RI No.1204/Menkes/SK/X/2004 Tentang Persyaratan Kesehatan Lingkungan Rumah Sakit, Jakarta

[3] Hapsari. 2010. Analisis Pengelolaan Sampah dengan Pendekatan Sistem di RSUD dr. Moewardi Surakarta, Tesis: Universitas Diponegoro Semarang

[4] Wiku Adisasmito, 2008, Audit Lingkungan Rumah Sakit, Jakarta : Rajawali Pers
* Berat maksimum sampah non medis Puskesmas dalam satu hari, yaitu:

Sampah Basah : $6.000 \mathrm{gr}$

Sampah Kering $: 10.370 \mathrm{gr}$

* Berat maksimum sampah medis perhari adalah 3820gr

* Limbah padat medis digolongkan menjadi 3 yaitu infeksius, infeksius benda tajam, dan farmasi

3. Rekomendasi

* Rekomendasi untuk limbah cair adalah dengan memperbaiki IPAL pada puskesmas yang telah memiliki IPAL dan pengecekan dosis klor. Puskesmas yang tidak memiliki IPAL dianjurkan membangun IPAL jenis Biofilter.

* Rekomendasi untuk limbah padat domestik dengan memisahkan sampah basah dan sampah kering. Pemberian label dengan jelas serta menggunakan kantong plastik berwarna hitam sesuai dengan PerMenKes.

* Rekomendasi untuk limbah medis adalah dengan memperbaiki TPS yang berada di Puskesmas agar sesuai dengan PP 101 Tahun 2014

\section{UCAPAN TERIMA KASIH}

Terselesaikannya penelitian ini. Ucapan terimakasih ditujukan kepada laboran pemulihan air dan manajemen kualitas lingkungan jurusan teknik lingkungan, Puskesmas di Surabaya Utara, Dinas 